\title{
Using systematic screening to increase integration of reproductive health services delivery in Senegal
}

Diouratie Sanogo

Population Council

Ricardo Vernon

Population Council

James R. Foreit

Population Council

Awa M. Coll-Seck

Colonel Adama Adoye

See next page for additional authors

Follow this and additional works at: https://knowledgecommons.popcouncil.org/departments_sbsr-rh

Part of the Demography, Population, and Ecology Commons, Health Services Research Commons, International Public Health Commons, Public Health Education and Promotion Commons, and the Women's Health Commons

How does access to this work benefit you? Let us know!

\section{Recommended Citation}

Sanogo, Diouratie, Ricardo Vernon, James R. Foreit, Awa M. Coll-Seck, Colonel Adama Adoye, Laty G. Ndoye, Cheikh Bamba Diop, Balla Mbacke Mboup, and Omar Sarr. 2005. "Using systematic screening to increase integration of reproductive health services delivery in Senegal," FRONTIERS Final Report. Washington, DC: Population Council. 


\section{Authors}

Diouratie Sanogo, Ricardo Vernon, James R. Foreit, Awa M. Coll-Seck, Colonel Adama Adoye, Laty G. Ndoye, Cheikh Bamba Diop, Balla Mbacke Mboup, and Omar Sarr 


\title{
Using Systematic Screening to Increase Integration of Reproductive Health Services Delivery in Senegal
}

\author{
Diouratié Sanogo, Ricardo Vernon, and James R. Foreit \\ Frontiers in Reproductive Health Program \\ Awa Seck, Colonel Adama Ndoye, Laty Ndoye, \\ Cheikh Bamba Diop, Balla Mbaké Mboup, and Omar Sarr \\ Senegal Ministry of Health
}

August 2005

This study was funded by the U.S. AGENCY FOR INTERNATIONAL DEVELOPMENT (USAID) under the terms of Cooperative Agreement number HRN-A-00-98-00012-00 and Population Council In-house Project No. 5800 13049. The opinions expressed herein are those of the authors and do not necessarily reflect the views of USAID. 


\section{ABSTRACT}

This study tested the systematic screening technique to increase the integration of reproductive health services in Senegal. The study took place in four urban health posts in the city of Dakar and three rural health posts in the district of Kebemer. A before and after design tested the hypothesis that the use of the systematic screening tool would result in more services received per client visit. In Dakar, services per visit increased significantly $(\mathrm{p}<.001)$ by 20 percent, while in Kebemer, services per visit also increased significantly $(\mathrm{p}<.001)$ by 35 percent. The study also examined several techniques to improve provider compliance with the screening technique. The Senegal Ministry of Health has requested assistance in scaling-up the strategy to other reproductive health service delivery points at district, regional, and national levels. 


\section{INTRODUCTION}

Following the 1994 Cairo International Conference on Population and Development (ICPD) Program of Action, the integration of reproductive health services became a priority of many programs. Integration is defined as the proactive provision of multiple reproductive health services in the same facility at the same time (Foreit, Hardee, and Agarwal 2002). The principal reason for integration is to reduce the unmet health care needs of clients. This implies that integration must be effective at the provider level. The Senegal Ministry of Health (MOH) has a policy requiring the integration of reproductive health services, but this policy has not been implemented at the provider level. Data from the 1998 Senegal Situation Analysis indicated that the majority of family planning clients received little or no information about other reproductive health issues, and that family planning was mentioned to only 12 percent of antenatal clients during the consultation (MOH and Population Council 1998). The MOH is aware of this situation and has been seeking to develop a solution for several years.

Most recently, the $\mathrm{MOH}$ decided to test systematic screening, a technique to increase the number of needed services received at a single client visit. In this strategy, providers use a checklist to identify the needs and desires for reproductive health services of women visiting the health facility, and provide these services during the same visit, scheduled appointment, or referral.

In addition to this study, the Frontiers in Reproductive Health Program (FRONTIERS) tested the effectiveness of screening in improving integration in three other countries - Bolivia, Honduras, and India. The studies shared a standard research protocol, somewhat modified in each country to accommodate local reproductive health priorities and data gathering constraints. These studies indicate that systematic screening is an effective technique for increasing integration, as measured by the number of services received per client visit. In India, the technique increased the number of services per visit by approximately 22 percent (Das et al. 2005) and in Bolivia by nine percent (Foreit, Vernon, and Hamel 2005). In Bolivia only about 40 percent of clients were screened, but screened clients received about 25 percent more services per visit than nonscreened clients. In Honduras the intervention was not thoroughly implemented as only 11 percent of visits were screened; however screened clients also received 22 percent more services than non-screened clients (Vernon et al. 2005). In an unrelated study in Peru, an experiment demonstrated that the technique increased services per visit by 13 percent (León et al. 1998).

This study tested the effectiveness of systematic screening in an African program setting, in both urban and rural areas. The objectives of the study were: (1) to determine if systematic screening would increase reproductive health services integration at the provider level; and (2) to determine if a shorter, checklist-type algorithm detected as many unmet needs as a longer questionnaire-type algorithm requiring longer training and additional administrative time. 


\section{METHODOLOGY}

Participants and Design: Women 15-49 years of age and children ages 0-4 years participated in the study. All were clients in three rural health posts in the district of Kebemer, or four health posts in the city of Dakar. The study was explained to all clients with the required profile, and those giving verbal informed consent (the modal post user is illiterate) were included in the study.

Nurses, nurse-midwives, and auxiliary nurses staffed all urban and rural health posts. The posts were somewhat underutilized. In Dakar the number of visits per day ranged from approximately 15 to 60, and in Kebemer from 15 to 30. All eighteen providers included in the study were trained to use the screening tool over a period of two and half days. Training consisted of an afternoon orientation, and two days practice in the use of the screening tool.

A before and after design compared the number of services received per client visit for six weeks before and six weeks after the introduction of screening. Although the design fails to control for factors such as secular trends, seasonality, or random fluctuations in the number of clients, the dependent variable is much more stable than the number of services or visits alone, justifying the use of the relatively low-power design, especially when time and budget constraints are taken into consideration. The length of the pre-and post-test observation periods permitted analysis of individual health post results.

A second study objective was to compare two screening forms, a brief questionnaire style, form "A", and a checklist style, form "B" (see Appendix). The form was randomly assigned to health posts. Two health posts in Dakar received form A, and two received form B. In Kebemer, two posts received form $A$ and one post received form B. In addition to quantitative comparisons between the two forms, focus group discussions were held to obtain provider feedback on such issues as ease of use of the forms and adequacy of training in each. Community health committee members' perceptions of the value of screening (all posts are supervised by a local committee) were also obtained through focus group discussions.

Intervention: The intervention consisted of providers screening all clients with either form A or $\mathrm{B}$ of the systematic screening instrument.

Dependent Variables: Two dependent variables were measured: (1) changes in the number of services received per client visit; and (2) changes in the number of appointments for additional services per client visit at the same health facility. Four services were included in the study: antenatal care, family planning, diagnosis and treatment of reproductive tract infections (RTI), and vaccination of children under five years of age. Other analyses included the percent of clients screened and the level of unmet need for services. Because services per visit are not normally distributed, a non-parametric statistic, the Mann-Whitney U, was used to test the differences between groups.

Procedure: The health service statistics system was not suitable for gathering all data needed by the study. Consequently, in addition to the routine daily services registers, three other sources were used to obtain data: (1) exit interviews; (2) screening instruments; and (3) focus group 
discussions. Twelve professional interviewers were trained for three days in the use of the exit questionnaire.

Exit interviews were used to obtain informed consent and determine the number and type of services received by clients during pre-and post-test visits to the health posts. During the pre-test period, only information on services received was obtained as screening was not yet implemented. Information on unmet need was collected during the post-test period. To avoid instrument bias, only interview results were used in the before and after comparisons.

All providers were asked to administer the screening forms. Women were first asked the reason for their visit. After this was established, the provider went on to identify unmet needs, and to record if the client was interested in receiving services for the detected needs. The nursing staff provided as many requested services as possible, and directed the client to the appropriate service within the same facility for services she could not provide. The outcome of the consultation was also recorded on the form.

Intervention Monitoring: Research staff made regular visits to the posts to collect questionnaires and forms. During these visits, problems in administering the instruments were identified and corrected. At each study site, one provider was responsible for reproductive health services at each post. During the study, these providers were also given the task of helping to ensure compliance with the intervention.

\section{RESULTS}

Implementation of the intervention: During the six-week intervention period, service providers appear to have screened virtually all clients who came for one of the four services included in the study. In rural posts, 1,472 completed screening forms were collected compared to 1,461 interviews. In urban posts, 3,831 screening forms were collected compared to 3,759 questionnaires. Interest in applying systematic screening probably aided compliance; several providers requested forms for use after the study.

Equivalence of groups: Approximately 5,600 clients visited the posts prior to the intervention, and 5,200 after the intervention. During the pre-intervention and post-intervention periods, in both areas, prenatal and childhood vaccination accounted for two-thirds of health post visits. In both rural and urban areas, before and after the intervention, the median age group was 25-27 years, and median education was incomplete primary schooling.

Comparison of screening forms: No statistically reliable differences $(\mathrm{p}<.05)$ between screening forms were found. In Dakar each version of the form detected a mean unmet need for 1.4 services per visit, while in Kebemer each version of the form detected a need for 1.8 services. The results suggest that shorter, checklist formats can screen as effectively as longer, questionnaire formats. However, during focus groups, many providers expressed a preference for the longer, but more highly structured form A, which they felt was more accurate and easier to use, once the provider was trained. Regardless of the form used, providers and health committee members were enthusiastic about the value of screening. 
Unmet service needs: To help in program planning, the Ministry of Health wished to obtain information on the type of and unmet need for services already being offered by health facilities. Table 1 shows unmet need for services in the Dakar and Kebemer posts among women who were screened for service needs in addition to the service initially requested.

Table 1. Unmet Need for Reproductive Health Services

\begin{tabular}{|l|c|c|}
\hline \multicolumn{1}{|c|}{ Service } & Dakar & Kebemer \\
\hline Antenatal Care & $\begin{array}{c}3 \% \\
(\mathrm{n}=152)\end{array}$ & $\begin{array}{c}3 \% \\
(\mathrm{n}=36)\end{array}$ \\
\hline Family Planning* & $\begin{array}{c}20 \% \\
(\mathrm{n}=387)\end{array}$ & $\begin{array}{c}45 \% \\
(\mathrm{n}=224)\end{array}$ \\
\hline Vaccination** & $\begin{array}{c}38 \% \\
(\mathrm{n}=959)\end{array}$ & $\begin{array}{c}36 \% \\
(\mathrm{n}=384)\end{array}$ \\
\hline STI/RTI & $\begin{array}{c}17 \% \\
(\mathrm{n}=277)\end{array}$ & $\begin{array}{c}28 \% \\
(\mathrm{n}=239)\end{array}$ \\
\hline \multicolumn{2}{|c|}{${ }^{*}$ Married Women 15-49 years of age } & \\
&
\end{tabular}

Women who responded they were pregnant but not attending a prenatal clinic were considered to have an unmet need for antenatal care. In fact, the most common reason for visiting the health posts was to receive antenatal care, explaining low unmet need for this service. The standard demographic definition of unmet need for contraception was used (i.e., women who were not pregnant, did not want to get pregnant, but were not contracepting). In both urban and rural posts, the greatest unmet need was for family planning. Children under 5 with incomplete vaccination were defined as having an unmet service need. Unmet need for immunization was high in both Dakar and Kebemer and, along with family planning, represents the greatest unmet need among health post clients. The syndromic approach was used to detect unmet needs for sexually transmitted infection/reproductive tract infection (STI/RTI) services. One-third of rural and one-fifth of urban clients responded that they had an STI/RTI symptom that they would like to discuss with a provider.

Services and appointments per visit: For all posts, the mean number of services per visit provided before the intervention was 1.23, and 1.51 after the intervention, a significant $(\mathrm{p}<.001)$ difference of 23 percent. In Dakar, services per visit increased by 20 percent, and in Kebemer by 35 percent, suggesting greater unmet needs in rural areas. For each post, services per visit was higher $(\mathrm{p}<.001)$ after the intervention than before the intervention, with percent increases ranging from seven to 41 percent. In both Dakar and Kebemer the modal number of services per visit increased from one to two. Statistical significance in this study is largely the product of the large sample size, ranging from 988 to 3,086, depending on the post. Of practical importance is the fact that all but one health post increased sevices per visit by over 10 percent.

Table 2 shows the mean number of services and appointments received before and after the intervention for all posts included in the study. Although the number of services increased, the intervention had no impact on the number of appointments per visit. The number was very small both before and after the intervention. Significant $(\mathrm{p}<.001)$ increases in appointments were found in only three of seven posts. Most absolute differences are approximately one to two percent. 
The small number of appointments may be a result of the inability of the health posts to accommodate more visits during the average working day, and/or the willingness of clients to wait for the additional services. No referrals were made during the study.

Table 2. Mean Services and Appointments per Visit by Health Post and Area

\begin{tabular}{|c|c|c|c|c|c|}
\hline \multirow[t]{2}{*}{ Health Posts } & \multicolumn{2}{|c|}{$\begin{array}{l}\text { Mean Services } \\
\text { per Visit }\end{array}$} & \multirow[t]{2}{*}{$\begin{array}{c}\% \\
\text { Change }\end{array}$} & \multicolumn{2}{|c|}{$\begin{array}{l}\text { Mean Appointments } \\
\text { per Visit }\end{array}$} \\
\hline & Pre & Post & & Pre & Post \\
\hline Total Dakar & 1.17 & $1.40^{*}$ & 20 & 0.15 & $0.20^{*}$ \\
\hline HLM1 & 1.20 & $1.51^{*}$ & 25 & 0.20 & 0.21 \\
\hline $\begin{array}{l}\text { Georges } \\
\text { Lahoud }\end{array}$ & 1.16 & $1.46^{\star}$ & 26 & 0.11 & 0.09 \\
\hline Derklé & 1.12 & $1.28^{\star}$ & 16 & 0.11 & $0.40^{*}$ \\
\hline Liberté IV & 1.21 & $1.30^{\star}$ & 7 & 0.10 & $0.01^{*}$ \\
\hline Total Kebemer & 1.44 & $1.79^{\star}$ & 35 & 0.18 & 0.20 \\
\hline Diokoul & 1.38 & $1.95^{\star}$ & 41 & 0.05 & 0.07 \\
\hline Gueoul & 1.61 & $1.81^{*}$ & 12 & 0.56 & 0.37 \\
\hline Sagatta & 1.27 & $1.59^{\star}$ & 25 & 0.40 & $0.56^{\star}$ \\
\hline
\end{tabular}

\section{DISSEMINATION AND UTILIZATION}

Two data presentation seminars were held. A local seminar was held for the staff of the participating health posts and health district officers. A national seminar followed, and the 50 participants included members of the $\mathrm{MOH}$ technical committee that supervised the experiment, central-level Ministry staff responsible for the nationwide delivery of reproductive health services, international donors, and technical assistance agencies. Participants at both seminars recommended that systematic screening be scaled-up nationally, beginning with the remainder of the health posts in the study districts. The national seminar also recommended the use of the simpler screening tool, and within-post supervision of systematic screening by a designated provider. The Ministry is seeking financial support to implement scale-up of the intervention.

\section{DISCUSSION}

This experiment demonstrated that systematic screening can be an effective intervention technique in African program settings. The intervention significantly increased services per visit. In Dakar the increase was 20 percent and in rural Kebemer, 35 percent. The results of this experiment are consistent with those of studies in Asia and Latin America. The robustness of the findings suggest that systematic screening may be considered a best practice by programs, donors, and technical assistance organizations. 
Provider compliance was a problem in systematic screening studies in Latin America, but compliance problems were not encountered in this study as virtually all clients were screened. The study may also contain lessons for improving compliance. Problems identified in other studies include lack of provider interest, lack of supervision, and clinic overcrowding. A limitation of the study, however, is the frequency of supervisory visits made by researchers. These visits supplemented the routine supervisory visits made by program staff and probably influenced compliance.

Focus group results suggested that providers were interested in systematic screening; a staff member in each health post was given responsibility for implementing the technique, and clinics were not overcrowded. The experiment's demonstration that a shorter instrument is as effective at detecting unmet needs as a longer instrument suggests that reducing instrument length is a viable technique for increasing screening in crowded services.

The Senegal Ministry of Health wishes to scale-up systematic screening, but the effectiveness of the intervention creates problems for implementation on a wider scale. The technique will improve provider productivity, but it will also increase program costs. In Senegal, just seven urban and rural posts received over 10,000 visits in a twelve-week period, and screening increased the number of services provided at those visits by approximately 2,300. If implemented nationally, an effective screening program would result in large variable cost increases and potentially important increases in fixed costs. Prior to scaling-up systematic screening, programs need to estimate potential cost increases and plan the pace and extent of scale-up accordingly. 


\section{REFERENCES}

Das, N. P. et al. 2005. "Systematic screening to meet unmet need by integrating reproductive health services: An operations research model to maximize service utilization," FRONTIERS Final Report, Washington, DC: Population Council.

Foreit, James R., Ricardo Vernon, and Patricia Riveros Hamel. 2005. "Use of systematic screening to increase the provision of reproductive health services in Bolivia," FRONTIERS Final Report, Washington, DC: Population Council.

Foreit, Karen G. Fleischman, Karen Hardee, and Kokila Agarwal. 2002. "When does it make sense to consider integrating STI and HIV services with family planning services?” International Family Planning Perspectives 28(2): 105-107.

León, Federico et al.1998. "Increasing use of reproductive health services in a Peruvian clinic,” in Family Planning Operations Research: A Book of Readings, eds. James R. Foreit and Tomas Frejka. New York: Population Council, pp. 239-245.

Ministry of Health and Population Council. 1998. "Evolution des services de santé de la reproduction et de planification familiale de 1994 à 1998,” Africa OR/TA II Rapport Final. Projet de Recherche Operationnelle et d'Assistance Technique en Afrique II. Dakar: Ministère de la Santé, Program National de Planification Familiale et Population Council.

Vernon, Ricardo et al. 2005. "Systematic screening as a strategy to increase services integration and revenues in Honduras,” FRONTIERS Final Report, Washington, DC: Population Council. 
APPENDIX

Systematic Screening Forms A and B 


\section{SCREENING FORM A}

\begin{tabular}{|c|c|c|c|c|}
\hline Q1. & Quelle est la raison principale de $\mathrm{v}$ & otre visite aujourd'hui ? & & RESULTAT \\
\hline Q2. & $\begin{array}{l}\text { Je voudrais vous poser quelques } \\
\text { questions pour voir s'il y a d'autres } \\
\text { services qui vous intéressent et que } \\
\text { vous pourrez recevoir pendant la } \\
\text { présente visite ou plus tard }\end{array}$ & $\begin{array}{l}\text { Si la raison principale de la visite est : } \\
1=\text { Consultation prénatale }: \rightarrow Q .3 \\
2=\text { Vaccination antitétanique }: \rightarrow Q .3 \\
3=\text { Planification familiale }: \rightarrow Q 4 \\
4=\text { Dépistage et traitement d'IST/ITG : } \\
\rightarrow \text { Q.3 \& Sauter Q.7 } \\
5=\text { Vaccination de l'enfant: } \rightarrow \text { Q.3 \& } \\
\quad \text { Sauter Q.9 } \\
6 \text { = Suivi croissance de l'enfant: } \rightarrow \text { Q. } 3 \\
\quad \text { \& Sauter Q.8 }\end{array}$ & $\begin{array}{l}\text { DISCUTER ET } \\
\text { ENCERCLER LE(S) } \\
\text { SERVICE(S) } \\
\text { DEMANDE(S) }\end{array}$ & $\begin{array}{l}\text { 1. Offert } \\
\text { 2. Planifié } \\
\text { 3. Référence } \\
\text { (Inscrire le } \\
\text { numéro correspond au } \\
\text { résultat de la visite }\end{array}$ \\
\hline Q3. & $\begin{array}{l}\text { Etes vous présentement } \\
\text { enceinte? } \\
\text { 1. Oui } \rightarrow \\
\text { 2. Non: Allez à Q.4 } \\
\text { 3. Ne sait pas : Allez à Q.4 }\end{array}$ & $\begin{array}{l}\text { Etes vous suivie en consultation } \\
\text { prénatale? } \\
\text { 1. Non } \rightarrow \\
\text { 2. Oui: Allez à Q.6 }\end{array}$ & $\begin{array}{c}\text { CPN } \\
\text { (Aller à 6) }\end{array}$ & \\
\hline Q4. & $\begin{array}{l}\text { Souhaiteriez-vous devenir } \\
\text { enceinte? } \\
\text { 1. Non } \rightarrow \\
\text { 2. Oui: Allez à Q.6 }\end{array}$ & $\begin{array}{l}\text { Utilisez-vous une méthode } \\
\text { contraceptive? } \\
\text { 1. Non } \rightarrow \\
\text { 2. Oui: Quelle } \\
\text { methode? } \quad \text { Allez à Q.5 }\end{array}$ & $\begin{array}{c}\text { PF } \\
\text { (Aller à 6) }\end{array}$ & \\
\hline Q5. & $\begin{array}{l}\text { Etes vous satisfaite avec votre } \\
\text { méthode contraceptive? } \\
\text { 1. Non } \rightarrow \\
\text { 2. Oui: Allez à Q.6 } \\
\text { 3. Ne sait pas : Allez à Q.6 }\end{array}$ & $\begin{array}{l}\text { Aimeriez-vous utiliser une autre } \\
\text { méthode contraceptive? } \\
\text { 1. Oui } \rightarrow \\
\text { 2. Non: Allez à Q.6 }\end{array}$ & $\begin{array}{c}\text { PF } \\
\text { (Aller à 6) }\end{array}$ & \\
\hline Q6. & $\begin{array}{l}\text { Avez-vous déjà reçu une } \\
\text { vaccination anti-tétanique ? } \\
\text { 1. Non } \rightarrow \\
\text { 2. Oui: Allez à Q.7 }\end{array}$ & $\begin{array}{l}\text { Aimeriez-vous la recevoir } \\
\text { aujourd'hui? } \\
\text { 1. Oui } \rightarrow \\
\text { 2. Non: Allez à Q.7 }\end{array}$ & $\begin{array}{c}\text { VAT } \\
\text { (Aller à 7) }\end{array}$ & \\
\hline Q7. & $\begin{array}{l}\text { Avez-vous un ou des signes } \\
\text { d'IST/ITG que vous voudriez discuter } \\
\text { avec le prestataire? } \\
\text { 1. Oui /Ne sait pas } \rightarrow \\
\text { 2. Non: Allez à Q.8 }\end{array}$ & $\begin{array}{l}\text { Aimeriez-vous être dépistée ou } \\
\text { avoir un traitement d'IST/ITG? } \\
\text { 1. Oui } \rightarrow \\
\text { 2. } \quad \text { Non: Allez à Q.8 }\end{array}$ & $\begin{array}{l}\text { IST/ITG } \\
\text { (Aller à 8) }\end{array}$ & \\
\hline Q8. & $\begin{array}{l}\text { Avez-vous des enfants de moins } \\
\text { de } 5 \text { ans? } \\
\text { 1. Oui } \rightarrow \\
\text { 2. Non: Allez Q.10 }\end{array}$ & $\begin{array}{l}\text { Bénéficient-ils d'une consultation } \\
\text { régulière pour le suivi de leur } \\
\text { croissance? } \\
\text { 1. Non } \rightarrow \\
\text { 2. Oui: Allez à Q.9 }\end{array}$ & $\begin{array}{l}\text { SUIVI CROISSANCE } \\
\text { (Aller à 9) }\end{array}$ & \\
\hline Q9. & $\begin{array}{l}\text { Tous vos enfants de moins de } 5 \\
\text { ans ont-ils été complétement vaccinés? } \\
\text { 1. Non/Ne sait pas } \rightarrow \\
\text { 2. Oui: Allez à Q.10 }\end{array}$ & $\begin{array}{l}\text { Aimeriez-vous vacciner vos } \\
\text { enfants aujourd'hui ou planifier leur } \\
\text { vaccination? } \\
\text { 1. Oui } \rightarrow \\
\text { 2. Non: Allez à Q.10 }\end{array}$ & $\begin{array}{l}\text { VACCINATION } \\
\text { ENFANT } \\
\text { (Aller à 10) }\end{array}$ & \\
\hline Q10. & $\begin{array}{l}\text { En dehors de ces services, y-en- } \\
\text { a-t-il d'autres qui vous intéressent et } \\
\text { que vous voudriez recevoir aujourd'hui } \\
\text { ou un autre jour? } \\
\text { 1. Oui } \rightarrow \\
\text { 2.Non: (FIN ) }\end{array}$ & $\begin{array}{l}\text { Lister le(s) service(s) } \\
1 . \\
2 . \\
3\end{array}$ & & \\
\hline
\end{tabular}




\section{SCREENING FORM B}

A remplir par le prestataire et à remettre à la cliente qui la présentera à l'enquêtrice à la sortie de la salle de consultation.

\begin{tabular}{|c|c|c|c|c|c|}
\hline \multicolumn{2}{|c|}{ Quel âge avez-vous? } & \multicolumn{4}{|c|}{ Noter la raison principale de la visite } \\
\hline \multirow{2}{*}{\multicolumn{3}{|c|}{$\begin{array}{l}\text { BESOIN (S) COMPLEMENTAIRE (S) } \\
\text { Avant la consultation, toujours demander à la cliente si, en } \\
\text { plus de la raison principale de la visite, elle aimerait recevoir } \\
\text { l'un des services suivants : (Encercler le numéro de code } \\
\text { correspondant ) }\end{array}$}} & \multicolumn{3}{|c|}{$\begin{array}{l}\text { RESULTATS DE LA VISITE } \\
\text { de consultation, toujours noter le } \\
\text { de la visite: (Inscrire le numéro de } \\
\text { respondant) }\end{array}$} \\
\hline & & & $\begin{array}{c}1 . \\
\text { Offert }\end{array}$ & $\begin{array}{c}2 . \\
\text { Rendez-vous }\end{array}$ & $\begin{array}{c}3 . \\
\text { Référence }\end{array}$ \\
\hline 1 & Consultation prénatale & & & & \\
\hline 2 & Vaccination antitétanique & & & & \\
\hline 3 & Consultation postnatale & & & & \\
\hline 4 & Planification familiale & & & & \\
\hline 5 & Dépistage et traitement d'IST/ITG & & & & \\
\hline 6 & Vaccination de l'enfant & & & & \\
\hline 7 & Suivi de la croissance de l'enfant & & & & \\
\hline
\end{tabular}

